\title{
Extraction of Antioxidants in Sweetpotato Waste Powder with Supercritical Carbon Dioxide
} \author{
Tsuyoshi UEHARA ${ }^{3}$ and Mikio KAWANO ${ }^{3}$

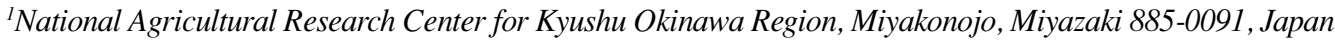 \\ ${ }^{2}$ National Institute of Crop Science, Tsukuba, Ibaraki 305-8518, Japan \\ ${ }^{3}$ Miyazaki Prefectural Food Development Center, Sadowara, Miyazaki 880-0303, Japan
}

Shigenori OKuno, ${ }^{1}$ Masaru Yoshinaga, ${ }^{1}$ Makoto NAKatani, ${ }^{2}$ Koji Ishiguro, ${ }^{1}$ Makoto Yoshimoto, ${ }^{1}$ Toshiro Morishita, ${ }^{3}$

Received October 9, 2001; Accepted February 12, 2002

\begin{abstract}
The application of supercritical carbon dioxide $\left(\mathrm{SC}-\mathrm{CO}_{2}\right)$ extraction to waste powder derived from sweetpotato roots with orange flesh in a food processing factory was examined. The contents of antioxidants, $\beta$-carotene, $\alpha$-tocopherol and chlorogenic acid, remaining in the waste powder after $\mathrm{SC}-\mathrm{CO}_{2}$ extraction under different conditions were determined by HPLC. At a constant extraction pressure, the extraction yield of $\beta$-carotene from the waste powder was highest at $40^{\circ} \mathrm{C}$, decreased at $60^{\circ} \mathrm{C}$ and decreased further at $80^{\circ} \mathrm{C}$; in contrast, the $\alpha$-tocopherol yield did not vary under different temperature conditions. At a constant extraction temperature, increasing extraction pressure increased the extraction yields of both $\beta$-carotene and $\alpha$-tocopherol. Under the conditions tested, the yields of $\beta$-carotene $(\mathbf{9 5 . 1 \%})$ and $\alpha$-tocopherol $(\mathbf{7 6 . 8 \%})$ were highest at $40^{\circ} \mathrm{C}$ and $35 \mathrm{MPa}$. Little chlorogenic acid was extracted from waste powder. The $\beta$-carotene remaining in the waste powder after $\mathrm{SC}-\mathrm{CO}_{2}$ extraction correlated well with its color value of $a^{*}$.
\end{abstract}

Keywords: sweetpotato, waste, powder, supercritical carbon dioxide, $\beta$-carotene, $\alpha$-tocopherol, chlorogenic acid

Sweetpotato is a very important upland crop in southern Japan and has been cultivated for table use and production of starch and liquor. Recently, Sunny Red, a new sweetpotato cultivar with orange flesh, was released for the utilization of its dried powder as raw materials for noodles, breads and confectionery (Kumagai et al., 1998). The main pigment in Sunny Red's storage roots is $\beta$-carotene (Takahata et al., 1993; Okuno et al., 1998); the roots also contain tocopherols, mainly $\alpha$-tocopherol (Okuno et al., 1998). These compounds are known to be hydrophobic antioxidants. Beta-carotene was shown to have many biological activities including antitumor-promoting activity (Murakoshi et al., 1992) and inhibition of cellular DNA breakage (Hiramoto et al., 1999). It has also been reported that consumption of a diet containing antioxidants such as $\beta$-carotene and tocopherols may reduce the plasma level of lipid peroxide (Singh et al., 1995). Sweetpotatoes also contain chlorogenic acid, which was shown to have such activities as antioxidative activity (Azuma et al., 1999), antihepatotoxic effects in mice (Kapil et al., 1995) and suppressing melanogenesis in cultured cells (Shimozono et al., 1996).

In the production of sweetpotato powder, waste powder was discarded, and this may impact the environment. Therefore, utilizing the waste powder can contribute to the production of valuable compounds and materials and the reduction of environmental impact.

A supercritical fluid, which is used above the critical temperature and critical pressure, has properties between gas and liquid

E-mail: sokuno@affrc.go.jp phases. Extraction with supercritical carbon dioxide $\left(\mathrm{SC}-\mathrm{CO}_{2}\right)$ has been widely applied in the area of food science and technology including applications such as extraction of oils (Stahl et al., 1984), carotenoid pigments (Degnan et al., 1991; Spanos et al., 1993) and a pesticide (Ambrosino et al., 1999) from plant materials. This technique has the following advantages compared with conventional processes of extraction with organic solvents and of distillation. Compounds extracted with $\mathrm{SC}-\mathrm{CO}_{2}$ have no toxic solvent residue because $\mathrm{SC}-\mathrm{CO}_{2}$ extraction does not require organic solvents and $\mathrm{SC}-\mathrm{CO}_{2}$ is itself non-toxic. The low temperature in $\mathrm{SC}-\mathrm{CO}_{2}$ extraction reduces thermal degradation of labile compounds and energy costs. $\mathrm{CO}_{2}$ is also inexpensive and readily available; it can be collected and recycled after extraction, reducing its release into the environment. As described above, there are many reports on the use of $\mathrm{SC}-\mathrm{CO}_{2}$ for extracting natural products from primary materials, including seeds, leaves and storage roots. In contrast, few studies have focused on the applicability of $\mathrm{SC}-\mathrm{CO}_{2}$ extraction for utilizing wastes and by-products discarded in food industries as sources of important compounds or materials.

The objective of this study was to investigate the potency of extraction with $\mathrm{SC}-\mathrm{CO}_{2}$ to utilize the waste powder derived from a process of powder production from a new sweetpotato cultivar, Sunny Red. The effects of SC- $\mathrm{CO}_{2}$ conditions on extraction of the important compounds, $\beta$-carotene, $\alpha$-tocopherol and chlorogenic acid, from the waste powder were examined.

\section{Materials and Methods}

Materials As standards for HPLC analysis, $\beta$-carotene 
was purchased from Sigma (St. Louis, MO), and chlorogenic acid and $\alpha$-tocopherol from Wako Pure Chemical Industries (Osaka). The waste powder from Sunny Red was a generous gift from a local food manufacturing company. Its moisture level was determined to be $9.6 \%(\mathrm{w} / \mathrm{w})$ by heating a sample $(5 \mathrm{~g})$ at $105^{\circ} \mathrm{C}$ for $2 \mathrm{~h}$ in an oven.

$\mathrm{SC}-\mathrm{CO}_{2}$ extraction Extraction experiments were performed on an SPE-1000 supercritical carbon dioxide extraction apparatus (Kobe Steel, Hyogo). The extraction vessel was 70 $\mathrm{mm}$ i.d. and $135 \mathrm{~mm}$ deep. One hundred grams $\left(218 \mathrm{~cm}^{3}\right)$ of the waste powder was placed in an extraction vessel for each condition. Carbon dioxide was supplied into the extraction vessel, and compressed and heated. Soon after the pressure and temperature reached the desired values, carbon dioxide was passed through a collection tube at $5 \mathrm{l} / \mathrm{min}$ for $2 \mathrm{~h}$ and an extract was collected. The waste powder before $\mathrm{SC}-\mathrm{CO}_{2}$ extraction and the powder residues after extraction were used in the experiments described below.

Quantification of $\beta$-carotene and a-tocopherol One milliliter of ethanol containing $0.1 \%$ (w/v) butylated hydroxytoluene (BHT) was added to $100 \mathrm{mg}$ of a powder sample in a centrifuge tube with a cap and mixed by a vortex mixer. To this mixture, 3 $\mathrm{ml}$ of $n$-hexane containing $0.05 \%$ (w/v) BHT was added followed by further mixing. After adding $1 \mathrm{ml}$ of water and mixing, the mixture was centrifuged at $2000 \mathrm{rpm}$ for $5 \mathrm{~min}$. The upper layer of the supernatant was collected and $3 \mathrm{ml}$ of $n$-hexane containing $0.05 \%(\mathrm{w} / \mathrm{v})$ BHT was added to the rest. After re-extraction, the resultant upper layer was combined and evaporated under a stream of nitrogen gas. The extract was redissolved in 1 $\mathrm{ml}$ of tetrahydrofuran containing $0.05 \%(\mathrm{w} / \mathrm{v})$ BHT and filtered through a membrane filter (DISMIC-13HP, pore size: $0.2 \mu \mathrm{m}$; ADVANTEC, Tokyon). A 10- $\mu$ l portion of the filtrate was injected into the HPLC system and eluted as described below. The HPLC system consisted of a Model LC-10AT pump, a Model SIL-10AXL autoinjector, a Model CTO-10AC column oven, a Model SPD-M10AVP photodiode array UV-VIS detector and a Model RF-10A spectrofluorometric detector (Shimadzu, Kyoto). The latter detector was connected to the outlet of the former. The system was controlled by a CLASS-LC10 workstation (Shimadzu). The column was a YMC-Pack ODS-A A-302 (150 mm×4.6 $\mathrm{mm}$ i.d., 5- $\mu \mathrm{m}$ particles; YMC, Kyoto). The temperature of the column oven was set at $40^{\circ} \mathrm{C}$. The mobile phase was methanol and the flow rate was $2 \mathrm{ml} / \mathrm{min}$. Beta-carotene was detected by the photodiode array detector at $460 \mathrm{~nm}$. Alpha-tocopherol was detected by the spectrofluorometric detector at $295 \mathrm{~nm}$ excitation and $325 \mathrm{~nm}$ emission.

Quantification of chlorogenic acid Six milliliters of methanol was added to $200 \mathrm{mg}$ of a powder sample in a centrifuge tube with a cap, mixed by a vortex mixer, heated in boiling water for 5 $\mathrm{min}$, and then shaken for $10 \mathrm{~min}$ at room temperature. After centrifugation at $2000 \mathrm{rpm}$ for $5 \mathrm{~min}$, the supernatant was collected. The precipitate was extracted twice with $6 \mathrm{ml}$ of methanol for 10 min at room temperature. The resulting supernatants were combined and concentrated in vacuo. The extract was redissolved in $2 \mathrm{ml}$ of methanol and filtered through a membrane filter. A $10-\mu \mathrm{l}$ portion of the filtrate was injected into the HPLC system and eluted as described below. Another pump was added to the system for determining chlorogenic acid content. The column was a YMC-Pack ODS-AM AM-302 (150 mm×4.6 mm i.d., 5- $\mu \mathrm{m}$
Table 1. Beta-carotene and $\alpha$-tocopherol contents of waste powder treated with supercritical $\mathrm{CO}_{2}$ under different pressure and temperature conditions.

\begin{tabular}{lccccc}
\hline $\begin{array}{c}\text { Pressure } \\
(\mathrm{MPa})\end{array}$ & $\begin{array}{c}\text { Temperature } \\
\left({ }^{\circ} \mathrm{C}\right)\end{array}$ & $\begin{array}{c}\beta \text {-carotene } \\
\text { (mg/100g, } \\
\text { powder) }\end{array}$ & $(\%)$ & $\begin{array}{c}\alpha \text {-tocopherol } \\
(\mathrm{mg} / 100 \mathrm{~g}, \\
\text { powder })\end{array}$ & $(\%)$ \\
\hline \multicolumn{2}{l}{ Before extraction } & 6.89 & 100 & 0.56 & 100 \\
25 & 40 & 0.52 & 7.5 & 0.17 & 30.4 \\
25 & 60 & 0.53 & 7.7 & 0.17 & 30.4 \\
25 & 80 & 0.97 & 14.1 & 0.17 & 30.4 \\
10 & 40 & 4.73 & 68.7 & 0.33 & 58.9 \\
15 & 40 & 1.33 & 19.3 & 0.27 & 48.2 \\
20 & 40 & 0.66 & 9.6 & 0.25 & 44.6 \\
30 & 40 & 0.50 & 7.3 & 0.15 & 26.8 \\
35 & 40 & 0.34 & 4.9 & 0.13 & 23.2 \\
\hline
\end{tabular}

SC-CO $\mathrm{Cl}_{2}$ flow rate, $300 \mathrm{l} / \mathrm{h}$; extraction period, $2 \mathrm{~h}$.

particles; YMC). The temperature was set at $40^{\circ} \mathrm{C}$. The mobile phase consisted of water containing $0.2 \%(\mathrm{v} / \mathrm{v})$ formic acid (A) and methanol containing $0.2 \%(\mathrm{v} / \mathrm{v})$ formic acid (B). Elution was performed with the linear gradient as follows: $2 \% \mathrm{~B}$ from 0 to 15 min and $2 \%$ to $45 \% \mathrm{~B}$ from 15 to $50 \mathrm{~min}$. The flow rate was 1 $\mathrm{ml} / \mathrm{min}$. Chlorogenic acid was detected at $326 \mathrm{~nm}$.

Measurement of color values A powder sample was placed in a plastic petri dish and the color values, $L^{*}, a^{*}$ and $b^{*}$, of the sample were measured by a CM-2002 color difference meter (Minolta, Tokyo). $L^{*}$ is a measure of lightness, and $a^{*}$ and $b^{*}$ indicate the green-red and blue-yellow axis, respectively (McGuire, 1992)

\section{Results and Discussion}

In processes of sweetpotato powder production in a food manufacturing company, sweetpotato roots are sliced without peeling, dried, milled and passed through a sieve (mesh size: 180 $\mu \mathrm{m})$. The material remaining on the sieve is waste powder without commercial value and is discarded. This waste powder was used in our experiments.

Table 1 shows the contents of $\beta$-carotene and $\alpha$-tocopherol in the powder residues obtained by treatment with $\mathrm{SC}-\mathrm{CO}_{2}$ under different temperature conditions. At a constant pressure of 25 $\mathrm{MPa}$, the extraction yield of $\beta$-carotene from the waste powder was the lowest at $80^{\circ} \mathrm{C}$, and extraction at $40^{\circ} \mathrm{C}$ was similar to that at $60^{\circ} \mathrm{C}$. From the viewpoint of energy costs in an extraction process, the condition at $40^{\circ} \mathrm{C}$ is more beneficial for $\beta$-carotene extraction than that at $60^{\circ} \mathrm{C}$. The extraction yields of $\alpha$-tocopherol were similar under the three temperature conditions. The reason for this difference in the temperature effect on extractability of $\beta$-carotene and $\alpha$-tocopherol is not clear. A co-factor in the waste powder may influence the extractability of $\alpha$-tocopherol; pure $\alpha$-tocopherol must be treated with $\mathrm{SC}-\mathrm{CO}_{2}$ in order to examine this possibility. It was also reported that extraction yields were independent of temperature in extraction of crude fat from rice bran (Taniguchi et al., 1987) and of limonoids from citrus seed meals (Ayano et al., 1992); however, the reason was not mentioned. In our experiments, we examined the influence of temperature on the extraction yields of compounds in the waste powder only at $25 \mathrm{MPa}$. Therefore, it is important to perform extraction experiments under various other pressure conditions.

We next examined the effects of $\mathrm{CO}_{2}$ pressure on the extraction yields of $\beta$-carotene and $\alpha$-tocopherol. As shown in Table 1 , the yields of $\beta$-carotene (95.1\%) and $\alpha$-tocopherol (76.8\%) were 


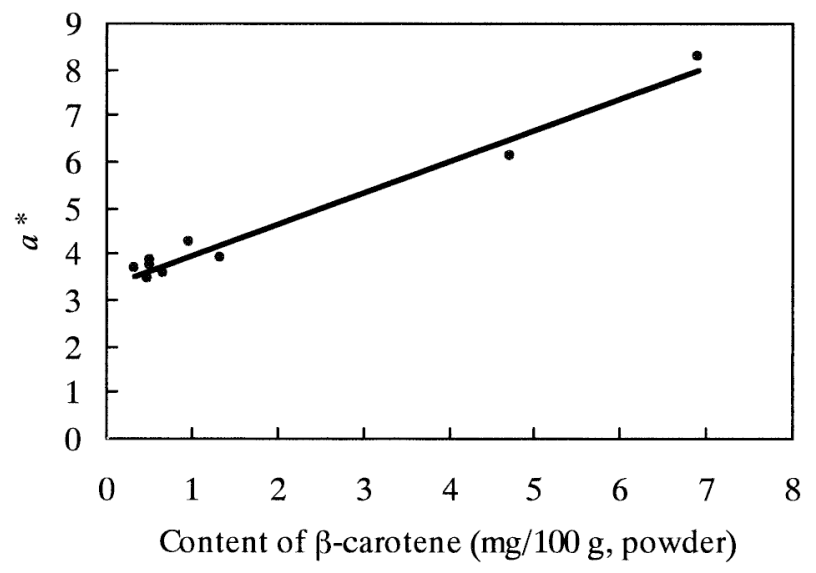

Fig. 1. Relationship between the color value of $a^{*}$ and $\beta$-carotene content of waste powder treated with and without $\mathrm{SC}-\mathrm{CO}_{2}(n=9)$.

highest at $35 \mathrm{MPa}$. These results revealed that the yields of both compounds increased as the $\mathrm{CO}_{2}$ pressure increased at a constant temperature of $40^{\circ} \mathrm{C}$. This tendency is consistent with that reported for extracting bixin from annatto seeds (Degnan et al., 1991), carotenoids from sweetpotato roots (Spanos et al., 1993) and lycopene from tomato skin (Inakuma et al., 1998). This may be because an increase in $\mathrm{SC}-\mathrm{CO}_{2}$ density with an increasing pressure leads to increased solubility of compounds in $\mathrm{SC}-\mathrm{CO}_{2}$ as described in previous reports. When $\mathrm{SC}-\mathrm{CO}_{2}$ was applied to extract carotenoids from sweetpotatoes, it was reported that $47.0 \%$ of the total carotenoid content was extracted from ovendried sweetpotato powder, and $64.4 \%$ was extracted from freezedried powder under the condition of $41.4 \mathrm{MPa}, 38^{\circ} \mathrm{C}$ and $1000 \mathrm{l}$ of the total $\mathrm{CO}_{2}$ volume at $14-18 \mathrm{l} / \mathrm{min}$ (Spanos et al., 1993). The particle sizes of these materials were between 250 and $420 \mu \mathrm{m}$. In contrast, $95.1 \%$ of the $\beta$-carotene in the waste powder was extracted under the condition of $35 \mathrm{MPa}, 40^{\circ} \mathrm{C}$ and $600 \mathrm{l}$ of the total $\mathrm{CO}_{2}$ volume at $300 \mathrm{l} / \mathrm{h}$ in our experiments (Table 1 ). The particle size of the waste powder exceeded $180 \mu \mathrm{m}$, but we did not perform further fractionation of the powder. The waste powder appeared to be heterogeneous to the naked eye and contained large particles derived from sweetpotato root epidermis. The higher extraction yield of carotenoids in our experiments may be due to the difference in content of small particles or in tissue structures of cultivars used. To clarify the influence of tissue structure on accessibility of SC- $\mathrm{CO}_{2}$ to the inside of the powder particles, it is important to compare extraction yields of carotenoids from different sweetpotato cultivars and to perform microscopic research on the powder particles.

The chlorogenic acid content in the waste powder before SC$\mathrm{CO}_{2}$ extraction was $19.4 \mathrm{mg} / 100 \mathrm{~g}$ and ranged from 17.8 to 19.4 $\mathrm{mg} / 100 \mathrm{~g}$ after extraction under the conditions tested (data not shown). This indicates that little chlorogenic acid was extracted with $\mathrm{SC}-\mathrm{CO}_{2}$ in contrast to $\beta$-carotene and $\alpha$-tocopherol. This result may be due to the higher polarity of chlorogenic acid than that of $\beta$-carotene and $\alpha$-tocopherol because $\mathrm{SC}-\mathrm{CO}_{2}$ is thought to behave similarly to hexane. It was also reported that bixin was extracted with $\mathrm{SC}-\mathrm{CO}_{2}$, but norbixin, which is more polar than bixin, was not extracted under the same conditions (Degnan et al., 1991).
Figure 1 shows the relationship between the color value of $a^{*}$ and the $\beta$-carotene content of the powder samples treated with and without $\mathrm{SC}-\mathrm{CO}_{2}(n=9)$. The correlation coefficient was 0.987 and was higher than that between the value of $L^{*}$ and $\beta$-carotene content $(0.486)$ and that between $b^{*}$ and $\beta$-carotene content (0.737) (data not shown). This indicates that removing $\beta$-carotene from the powder samples was most closely related to a decrease in the color value of $a^{*}$. Such a relationship was reported between the color value of the cut surface of raw sweetpotatoes with orange flesh and their $\beta$-carotene content (Takahata et al., 1993).

It was recently reported that $\mathrm{SC}-\mathrm{CO}_{2}$ was applied to extract lycopene from tomato skin derived from the production of tomato juice (Inakuma et al., 1998). In that study, tomato skin drying conditions were examined and dried samples were subjected to $\mathrm{SC}-\mathrm{CO}_{2}$ extraction. In general, materials with high moisture content are not suitable for usual SC-CO $\mathrm{CO}_{2}$ extraction. In our present study, the waste powder produced in drying processes in a factory was treated with $\mathrm{SC}-\mathrm{CO}_{2}$; therefore, examination of the drying conditions was not necessary. The results obtained in the present study revealed the possibility of extracting some important compounds such as hydrophobic antioxidants from waste materials with $\mathrm{SC}-\mathrm{CO}_{2}$. Because drying materials with high moisture levels requires costly energy, $\mathrm{SC}-\mathrm{CO}_{2}$ extraction can contribute to utilizing wastes or by-products with low moisture levels produced in drying processes in food and agricultural industries. If a good sweetpotato cultivar containing important enzymes or proteins together with pigments such as carotenoids is developed, $\mathrm{SC}-\mathrm{CO}_{2}$ extraction can serve to utilize it sequentially, i.e., to selectively extract pigments by $\mathrm{SC}-\mathrm{CO}_{2}$, and then use the remaining enzymes or proteins. This processing method can completely utilize sweetpotato cultivars having multiple valuable functions that are expected to be developed.

\section{References}

Ambrosino, P., Fresa, R., Fogliano, V., Monti, S.M. and Ritieni, A. (1999). Extraction of azadirachtin A from neem seed kernels by supercritical fluid and its evaluation by HPLC and LC/MS. J. Agric. Food Chem., 47, 5252-5256.

Ayano, S., Ozaki, Y., Inaba, N., Miyake, M., Maeda, H., Ifuku, Y. and Hasegawa, S. (1992). Extraction of limonoids and limonoid glucosides with supercritical carbon dioxide. Nippon Shokuhin Kogyo Gakkaishi, 39, 684-689 (in Japanese).

Azuma, K., Nakayama, M., Koshioka, M., Ippoushi, K., Yamaguchi, Y., Kohata, K., Yamauchi, Y., Ito, H. and Higashio, H. (1999). Phenolic antioxidants from the leaves of Corchorus olitorius L. J. Agric. Food Chem., 47, 3963-3966.

Degnan, A.J., Von Elbe, J.H. and Hartel, R.W. (1991). Extraction of annatto seed pigment by supercritical carbon dioxide. J. Food Sci., 56, $1655-1659$.

Hiramoto, K., Tomiyama, S. and Kikugawa, K. (1999). Effective inhibition by $\beta$-carotene of cellular DNA breaking induced by peroxynitrous acid. Free Rad. Res., 30, 21-27.

Inakuma, T., Yasumoto, M., Koguchi, M. and Kobayashi, T. (1998). Effect of drying methods on extraction of lycopene in tomato skin with supercritical carbon dioxide. Nippon Shokuhin Kagaku Kogaku Kaishi, 45, 740-743 (in Japanese).

Kapil, A., Koul, I.B. and Suri, O.P. (1995). Antihepatotoxic effects of chlorogenic acid from Anthocephalus cadamba. Phytother. Res., 9, 189-193.

Kumagai, T., Yamakawa, O. and Ishiguro, K. (1998). "Sunny Red: new sweetpotato cultivar for powder." Sweetpotato Res. Front, 7, 2.

McGuire, R.G. (1992). Reporting of objective color measurements. HortScience, 27, 1254-1255. 
Murakoshi, M., Nishino, H., Satomi, Y., Takayasu, J., Hasegawa, T., Tokuda, H., Iwashima, A., Okuzumi, J., Okabe, H., Kitano, H. and Iwasaki, R. (1992). Potent preventive action of $\alpha$-carotene against carcinogenesis: spontaneous liver carcinogenesis and promoting stage of lung and skin carcinogenesis in mice are suppressed more effectively by $\alpha$-carotene than by $\beta$-carotene. Cancer Res., 52, 6583-6587.

Okuno, S., Yoshimoto, M., Kumagai, T. and Yamakawa, O. (1998). Contents of $\beta$-carotene and $\alpha$-tocopherol of sweetpotato cultivars newly developed for processing purpose. Trop. Agric., 75, 174-176.

Shimozono, H., Kobori, M., Shinmoto, H. and Tsushida, T. (1996). Suppression of the melanogenesis of mouse melanoma B 16 cells by sweet potato extract. Nippon Shokuhin Kagaku Kogaku Kaishi, 43, 313-317 (in Japanese).

Singh, R.B., Niaz, M.A., Agarwal, P., Begom, R. and Rastogi, S.S.
(1995). Effect of antioxidant-rich foods on plasma ascorbic acid, cardiac enzyme, and lipid peroxide levels in patients hospitalized with acute myocardial infarction. J. Am. Diet. Assoc., 95, 775-780.

Spanos, G.A., Chen, H. and Schwartz, S.J. (1993). Supercritical $\mathrm{CO}_{2}$ extraction of $\beta$-carotene from sweet potatoes. J. Food Sci., 58, 817820.

Stahl, E., Quirin, K.W. and Blagrove, R.J. (1984). Extraction of seed oils with supercritical carbon dioxide: Effect on residual proteins. $J$. Agric. Food Chem., 32, 938-940.

Takahata, Y., Noda, T. and Nagata, T. (1993). HPLC determination of $\beta$-carotene content of sweet potato cultivars and its relationship with color values. Jpn. J. Breed., 43, 421-427.

Taniguchi, M., Tsuji, T., Morimoto, H., Shibata, M. and Kobayashi, T. (1987). Treatment of rice bran with supercritical carbon dioxide. Nippon Shokuhin Kogyo Gakkaishi, 34, 102-108 (in Japanese). 